\section{Acknowledgements}

Robert Nero and Peter Taylor were most helpful by commenting on a draft of the manuscript and by bringing a number of sightings to my attention. I thank them both.

${ }^{1}$ LAHRMAN, F. 1957. A quick-witted yellowlegs. Blue Jay 15:146.

${ }^{2}$ NERO, R.W. 1958. Attempted predation by Peregrine Falcon observed at Regina. Blue Jay 16:114.
${ }^{3}$ PARMELEE, D.F. In BENT. 1968. Life histories of North American cardinals, grosbeaks, buntings, towhees, finches, sparrows, and allies. U.S. Nat. Mus. Bull. 237, Smithsonian Institution Press, pp. 1652-1675.

${ }^{4}$ TAYLOR, P. 1983. Wings along the Winnipeg: the birds of the Pinawa-Lac du Bonnet region, Manitoba. Man. Nat. Soc. Eco Series No. 2, Winnipeg, Manitoba. 216 pp.

${ }^{5}$ WALLACE, R. 1958. Attempted predation by Peregrine Falcon observed at Toronto Island. Blue Jay 16:114.

\title{
GREENWATER LAKE BIRDS - A PERSONAL REMINISCENCE OF THE 1940s
}

DAVID H. WRIGHT, 1601-415 Heritage Crescent, Saskatoon, Saskatchewan. S7H 5N3

Greenwater Lake is situated in one of Saskatchewan's provincial parks. Now it is a well-developed summer resort with a trailer park, ample sandy beaches and most of the amenities North Americans expect during a summer vacation. When I was a teenager, the park was not nearly so sophisticated.

The lake is located in the east-central portion of the province in a well-treed area that might best be described as deciduous parkland. During the late 1940s, my parents acquired a small cottage after struggling for several years with a shack tent. The cottage was comfortable, but very modest. A small screened porch on the front served as an additional sleeping area.

Our summer vacations can only be described as idyllic. We spent our days fishing, swimming, exploring the woods on foot, and the lake and its creeks by boat. Swimming trunks were our summer uniforms.
In 1944, I was given Taverner's Birds of Canada. I later acquired a companion volume entitled Water Birds of Canada by the same author. With these books, a passing interest in birds developed into a lifelong hobby. For the first time, I observed that the so-called "Hell-diver" pointed out to me by others had plumage quite different to that of the loon. I discovered the numerous small "ducks" I saw swimming the reedy borders of the lake were not ducks at all, but something called coots. And so it went. The observations recorded below were made in the years 1944 through 1947 and characteristically in each year between approximately 25 June and 30 August. The one exception relates to the sighting of the White-breasted Nuthatch which I saw in the fall of 1947 while visiting Nut Mountain Lake.

The self-taught ornithologist is a sorry student. His mistakes are many, his progress (if any) slow. He may labour for years, learning what the professionally- 
taught student learns in three or four well-supervised field trips. The importance of shape, size, flight and posture are concepts learned after long and painful experience.

My observations during these summers were dutifully recorded on a card, but, alas, with little or no supporting detail. The youthful observer who sees an Osprey at regular intervals over a period of 2 months may not feel any need to record location, date, weather and activity. If he sees a Scarlet Tanager but once in his young life, he will probably be more fastidious.

My recollections of Greenwater are a collage of sights and sounds. From these I have tried to reconstruct a factual record of the birdlife of Greenwater Lake Park as seen through the eyes of the young, amateur ornithologist.

The lake itself was the great wellspring of sights and sounds. The first sounds of morning were the pluckings and splashings of the Red-necked Grebes, the last sound at night the spine-chilling call of the Common Loon. The reeds of the lake sheltered Pied-billed Grebes, American Bitterns, Great Blue Herons and the shy Sora. As my brother and I rode quietly through the slippery green cattail, we could see countless grebe eggs, casualties, we concluded, of spring and summer storms. Many coots nested in the areas of the dead brown reeds and shallower water of brackish bays. Occasionally I saw a less common swimmer, my one and only Western Grebe, and an occasional Doublecrested Cormorant.

One of the park's chief claims to fame was the large colony of American White Pelicans that lived on its northern shore. Fishermen muttered about the great bird's appetite for fish and, as a fisherman, I had my doubts. The pelicans flourished, however, and so did the fishermen.

1 always thought that the lake belonged to the grebes and the waders. There were many ducks. Mallards were so common that I simply noted their presence, as I did the presence of less com-

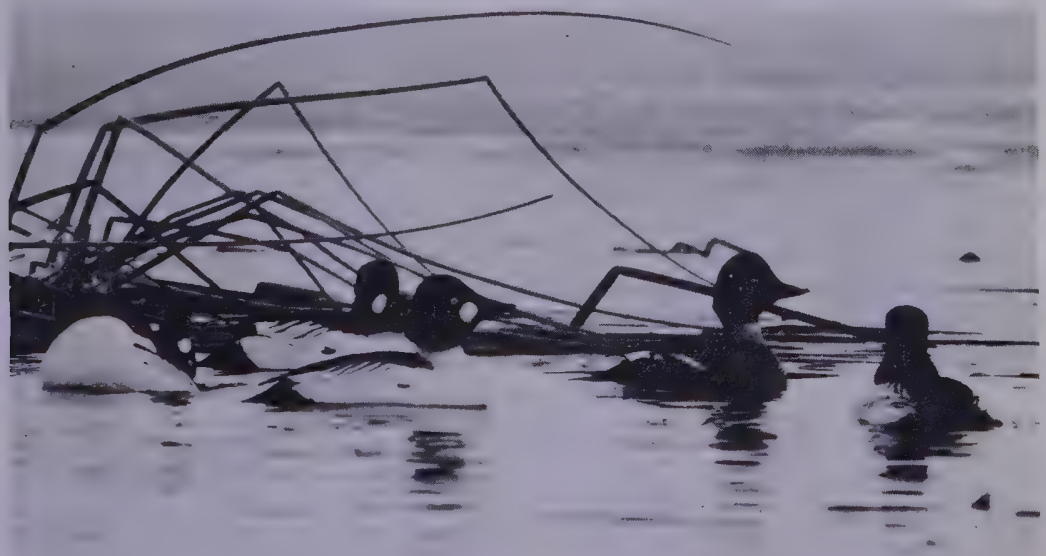


mon species, such as the Northern Pintail, Northern Shoveler, Canvasback and the scaups. Blue-winged Teal often crossed our paths, flying at great speed. I remember my one observation of a male Ruddy Duck as it swam nervously in the expanse of the lake.

The most typical duck it seems to me was the Common Goldeneye. We saw adult birds everywhere. They seemed to have large and well-tended families. I thought this to be the commonest duck at the lake.

The other species most identified in my mind with Greenwater was the Turkey Vulture. We often saw the adults circling high above the lake, their characteristic shape silhouetted against the bright summer sky. These birds could be seen roosting on the stumps of fallen trees along the lakeshore and taking in the summer sun. Their appearance did not encourage us to look for the nests that were probably situated at the base of the upturned trees.

We often saw Red-tailed Hawks around the lake. The other sighting which made a great impression on me was of a male Peregrine Falcon pursuing a Mallard at great speed as we sat in our boat fishing between the points of the lake.

The first species I can recall making any real impression on me was the Common Yellowthroat. I was so taken by its spectacular plumage that I can remember doing a water-colour painting soon afterwards. It would be more than. 30 years before I ever saw another.

As to the other species that 1 have noted in the following list, in many instances I observed either a nest or young or both, and I have tried as much as possible to note where that occurred. Perhaps the observations I have recorded will be of some assistance to other observers as the years unfold. The list represents as much as anything a record of an extremely happy and fulfilling time in my young life and one that I look back on with a great deal of pleasure.
All species were observed at some length in good to excellent light. Doubtful observations are not listed. I have not listed an isolated sighting of what was probably a Scarlet Tanager (male).

KEY: (c) common; (u) uncommon: (r) rare; (?) no record of frequency in observer's notes; (n) nest observed; and (y) young

Common Loon $(c, n, y)$, Pied-billed Grebe (u), Red-necked Grebe $(c, n, y)$, Western Grebe ( $r$ ), American White Pelican (c), Double-crested Cormorant ( $r$ ), American Bittern (c), Great Blue Heron (u), Mallard (c,y), Northern Pintail (r), Blue-winged Teal (c), Northern Shoveler ( $r$ ), Canvasback (u), Lesser Scaup (u), Common Goldeneye $(c, y)$, Ruddy Duck ( $r)$

Turkey Vulture (c), Osprey (u), Northern Harrier (c), Broad-winged Hawk ( $r$ ), Red-tailed Hawk (u), American Kestrel (u), Peregrine Falcon (r), Ruffed Grouse (u), Sora (c), American Coot $(c, n, y)$, Killdeer (c), Greater Yellowlegs (c), Lesser Yellowlegs (c), Solitary Sandpiper (c), Spotted Sandpiper (c), Least Sandpiper (u), Common Snipe ( $r$ )

Franklin's Gull (u), Ring-billed Gull (c), California Gull (c), Herring Gull (c,y), Common Tern (c,y), Black Tern (c), Mourning Dove (u), Black-billed Cuckoo (r), Great Horned Owl (c), Common Nighthawk (u), Rubythroated Hummingbird (r), Belted Kingfisher (u), Yellow-bellied Sapsucker (c), Downy Woodpecker (c), Hairy Woodpecker (c), Northern Flicker (c), Pileated Woodpecker ( $r)$

Western Wood-Pewee (c), Least Flycatcher (c), Eastern Phoebe (c), Great Crested Flycatcher (r), Eastern Kingbird (c), Purple Martin (r), Tree Swallow (c), Bank Swallow (c), Barn Swallow $(c, n, y)$, Blue Jay (c), Black-billed Magpie (c), American Crow (c), Common Raven (c), Black-capped Chickadee (c), Whitebreasted Nuthatch (?), House Wren (c), Mountain Bluebird (c), Veery (?), Hermit Thrush (c), American Robin (c), Gray Catbird (u), Brown Thrasher (c), Cedar Waxwing (c), Loggerhead Shrike (c)

Solitary Vireo (u), Philadelphia Vireo (u), Red-eyed Vireo (c), Yellow Warbler (c), Yellow-rumped Warbler (c), Black-and-white Warbler (c), American Redstart (c), Ovenbird (u), Northern Waterthrush ( $r$ ), Common Yellowthroat ( $r)$, Rose-breasted Grosbeak ( $r$ ), Rufous-sided Towhee ( $r$ ), American Tree Sparrow $(r)^{*}$, Chipping Sparrow (c), Clay-colored Sparrow (u), Vesper Sparrow (c), Fox Sparrow (u), Song Sparrow (c), White-throated Sparrow (c), Dark-eyed Junco (c) 
Red-winged Blackbird (c), Western Meadowlark (u), Yellow-headed Blackbird ( $r$ ), Rusty Blackbird (c), Brewer's Blackbird (u), Common Grackle (c), Brown-headed Cowbird (c), Northern Oriole (c), Purple Finch (?), Pine Siskin (?), American Goldfinch (c), House Sparrow $(u)$
*Upon receiving my report on the sighting of the American Tree Sparrow, which occurred in late June, Maurice G. Street expressed some doubt about it. I felt obliged to mention it, however, because I saw the individual bird for several minutes in excellent light.

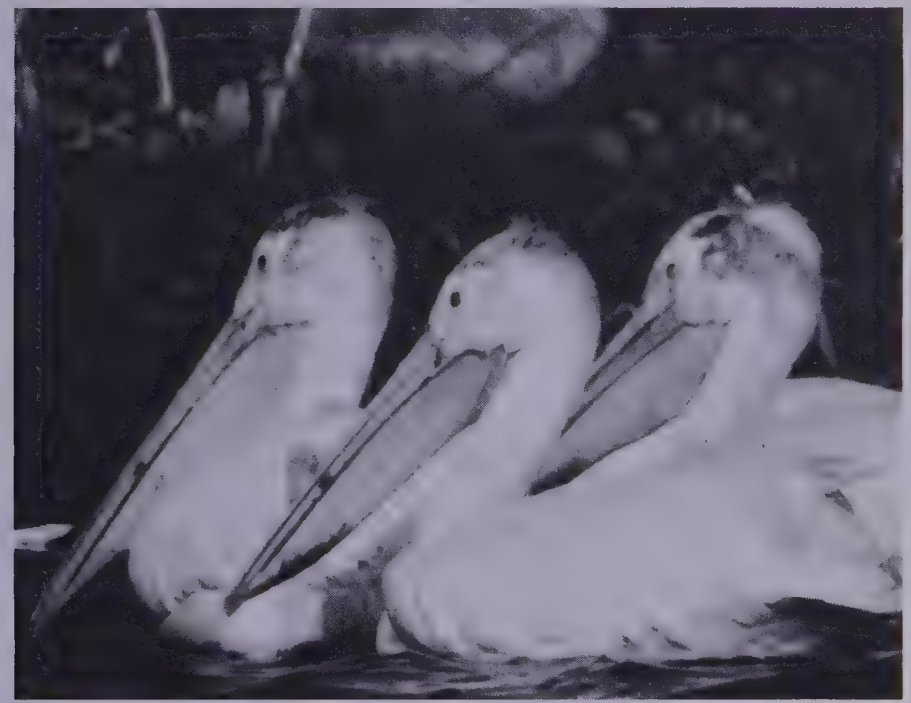

\section{ERRATIC FLIGHT OF A DOWNY WOODPECKER}

FRANK H. BRAZIER, 2657 Cameron Street, Regina, Saskatchewan. S4T 2W5

On 19 March 1989 at 10:00 a.m., under a heavily overcast sky, I stepped onto the parking lot in the southwestern angle of the Legislative Building in Regina. I heard the call of a Downy Woodpecker coming from a grove of trees immediately south of the parking lot. I was crossing the lot scanning the grove when a small bird shot out of the group of trees and gave a display of aerobatics I have never seen equalled.
The bird flew at such a rate that it literally disappeared and only the white in the plumage enabled me to follow it at all. It shot upwards, perhaps 30 feet, "jinked" and sped downwards at an acute angle into a shrub; then, without pause, it shot upwards to about the same height, snapped into a reverse and dove at high speed into the shrubbery at the east side of the lot. Then, again without pause, it shot out and into the shrubbery 